\title{
Regional zoogeographical zoning using species distribution modelling by the example of small mammals of South-Eastern Transbaikalia
}

\author{
Ekaterina V. Obolenskaya* \& Andrey A. Lissovsky
}

\begin{abstract}
Zoogeographical studies of regional scale always deal with incompleteness of faunal information. Such information is usually available as a set of localities, covering the studied area as an irregular network. At the same time, full coverage of data is needed for any spatial analysis. In this study, we attempted to perform faunal zoning at a regional level, formalising the procedure to the greatest extent possible. We used 47 small mammal species distribution models (SDM) as initial data for faunal zoning. SDMs were previously constructed based on localities determined using museum labels and environmental data with the maximum entropy method. SDMs were converted to binary values using fixed threshold. We calculated 1-Jaccard similarity coefficients between unique sets of predicted species compositions in each raster cell. The resulting dissimilarity matrix was analysed using hierarchical cluster analysis with the Ward and unweighted average methods. We distinguished three large clusters with nine subclusters based the similarity of the fauna composition. Patterns of the spatial distribution of species numbers and species composition homogeneity were obtained. The relationships between the distribution of species richness and the spatial heterogeneity of the fauna with latitude, longitude, altitude and environmental factors were studied using regression and discriminant analysis. Finally, two faunas were found in South-Eastern Transbaikalia, and a large territory in this region is occupied by a zone of their interpenetration. Analysis of stacked SDMs proposed as important tool for investigation of regional zoogeographical heterogeneity. It is especially useful for extrapolation of faunal data to a larger unstudied territory.
\end{abstract}

KEY WORDS: small mammals, species distribution model, environmental factors, Transbaikalia, zoogeographic zoning.

Ekaterina V. Obolenskaya [obolenskaya@zmmu.msu.ru] and Andrey A. Lissovsky [andlis@zmmu.msu.ru], Zoological Museum of Moscow State University, Bolshaya Nikitskaya 6, Moscow 125009, Russia.

\section{Региональное зоогеографическое районирование с использованием моделирования распространения видов на примере мелких млекопитающих Юго-Восточного Забайкалья}

\section{Е.В. Оболенская, А.А. Лисовский}

РЕЗЮМЕ. Зоогеографические исследования, выполненные в региональном масштабе, всегда сталкиваются с неполнотой фаунистической информации. Такая информация, как правило, представлена в виде набора локалитетов, покрывающих исследуемую территорию нерегулярной сетью. В то же время, полное покрытие фаунистическими данными территории необходимо для любого пространственного анализа. В этом исследовании мы попытались провести фаунистическое районирование регионального уровня, максимально возможно формализовав методику. В качестве исходных данных для фаунистического районирования мы использовали 47 моделей распространения мелких млекопитающих. Модели построены методом максимальной энтропии на основании точек находок, определенных по музейным этикеткам, и экологических данных. Модели были преобразованы в двоичные значения, используя фиксированный порог. Мы рассчитали, коэффициенты различия (1-коэффициент сходства Жаккара) между уникальными наборами сочетаний видов для каждой ячейки растра. Результирующая матрица различий была проанализирована с помощью иерархического кластерного анализа методом Уорда и UPGMA. На основе сходства состава фауны региона мы выделили три крупных кластера с девятью подкластерами. Были выявлены закономерности пространственного распределения количества видов и однородности видового состава. Взаимосвязь между распределением видового богатства и пространственной неоднородностью фауны с широтой, долготой, высотой местности над уровнем моря и факторами окружающей среды факторов были изучены с помощью регрессионного и дискриминантного анализа. В итоге в Юго- 
Восточном Забайкалье были обнаружены две фауны, и большая зона их взаимопроникновения. Анализ моделей распространения видов предлагается в качестве важного инструмента для изучения региональной зоогеографической неоднородности. Это особенно полезно для экстраполяции фаунистических данных для большой малоизученной территории.

КЛЮЧЕВЫЕ СЛОВА: мелкие млекопитающие, моделирование распространения видов, природные факторы, Забайкалье, зоогеографическое районирование.

\section{Introduction}

Since the first attempts at faunal zoning, one of the main tasks of zoogeography has been the development of methods (Sclater, 1858; Wallace, 1876; Severtsov, 1877; Semenov-Tyan-Shanskiy, 1936; Darlington, 1957; Hagmeier \& Stults, 1964; Simpson, 1964; Hagmeier, 1966; Kimoto, 1966; Udvardy, 1975; Skulkin \& Puzachenko, 1986; Márquez et al., 1997; Olivero et al., 2013; Ravkin et al., 2013). In comparison with global scale zoogeographical studies, regional or local scale studies present unique questions and methodological problems. If the study of thousands of distribution ranges worldwide is amenable to local scale generalisation, then the construction of detailed range boundaries based on a limited set of known locations is a separate and complicated problem.

Analyses of publications on regional theriofaunal zoning have demonstrated a notable diversity of methodologies (Kucheruk, 1959; Afanasyev, 1960; Matyushkin et al., 1972; Chernyavskiy, 1978; Tupikova, 1982; Neronov \& Arsenyeva, 1980; Shvetsov et al., 1984; Skulkin \& Puzachenko, 1986; Varshavskiy et al., 1997; Badgley \& Fox, 2000; Lyamkin, 2002; Xiang et al., 2004; Heikinheimo et al., 2007; Escalante et al., 2010; Nobrega \& Marco, 2011). Unlike studies on the zoning of all terrestrial areas or Palearctic, ecological approaches have been predominant in zoogeographical studies conducted on a local or regional scale (Bannikov, 1954a,b; Matyushkin, 1972; Yudin et al., 1979; Lyamkin, 2002). This approach is quite logical because regional-level zoning is more often associated with species ranges, which are largely determined by landscape-zonal conditions.

One of the methodological problems, based on the analysis of publications, is the primary choice of spatial units for zoogeographical analysis. In practice, this problem is often solved in two ways. First, units of previous physiographic or zoogeographic zoning can be taken as primary units for analysis (Yudin et al., 1979; Shvetsov et al., 1984; Márquez et al., 2001; Xiang et al., 2004). Second, networks of regular squares have been successfully used in studies on regional scale zoning in the USA, Canada, Iran, Afghanistan, Mongolia, China, Europe and other regions (Hagmeier \& Stults, 1964; Simpson, 1964; Kaiser et al., 1972; Wilson, 1974; Neronov, 1976; Neronov \& Arsenyeva, 1980; Skulkin \& Puzachenko, 1986; Márquez et al., 1997; Heikinheimo et al., 2007; Escalante et al., 2010; Barbosa et al., 2012).
Another methodology problem affecting the study of regional zoogeography is the heterogeneous distribution of faunal information in the territory of the region under consideration. Faunal information is usually available as a set of localities, covering the studied area as an irregular network. At the same time, full spatial coverage of faunal data is needed for typification or faunal zoning. When working on a global scale, we can roughly estimate ranges as continuous polygonal objects; the fine «lace» of the range with all of its gaps and isolates is the core value itself when studying a small territory.

Most zoning methods suppose a subdivision of a territory into a set of units that contain information on the local fauna. However, it is virtually impossible to collect "complete" information on faunal distributions within "regions" such as Mongolia, Kazakhstan or northeast Siberia. Researchers must restrict themselves to a limited number of reference points and extrapolate the data contained therein.

We can distinguish at least two theoretical approaches to the extrapolation of faunal data (Ferrier \& Guisan, 2006). The first method is the analysis of faunal data only from localities with available faunal information. In this case, the extrapolation can be performed at the level of the fauna identified during the analysis. However, in this case, an a priori limit is determined by the set of faunas (lists of taxa) that were directly observed by the investigator. In practice, the identification of a complete species list for any particular territory is an extremely difficult task. Thus, this approach has a certain initial error. The second method is the extrapolation of the distribution of each species, with a consequent analysis of the spatial heterogeneity of the stacked distributions. Algorithms for spatial extrapolation are well developed within the modern framework of the "species distribution modelling" approach.

The choice of a faunal typification method is a more technical task that has not substantially changed since the work of Wallace. Currently, this approach involves searching for a method to compare lists of taxa. One of the traditional methods of typification is cluster analysis using similarity indices, such as the Jaccard (Jaccard, 1901) or Simpson (Simpson, 1960) coefficients, as distance metrics.

In this study, we attempted to perform faunal zoning at a regional level, formalising the procedure to the greatest extent possible. We used species distribution models as the initial data, formal networks as the territorial units, and cluster analysis as the classification method. 




Figure 1. South-Eastern Transbaikalia. The map is presented using the Kavraiskiy conical intermediate projection.

We chose South-Eastern Transbaikalia as a model territory. The natural conditions of South-Eastern Transbaikalia are largely dependent on the mountainous relief (Vosskresenskiy \& Postolenko, 1967; Olyunin, 1975). This includes notable differences in the river network density between the northern and southern parts of the region. The region is also characterised by a continental climate regime (Arefyeva et al., 1965; Shpolyanskaya, 1978) and is positioned at the junction of Euro-Siberian dark coniferous and East Siberian light coniferous forests with the steppes of Mongolia and the Far East (Peshkova, 1985; Tahtadzhan, 1986; Galanin et al., 2009), resulting in notable patchiness and distinct landscapes (Mikheev \& Ryashin, 1967; Isachenko, 1985). These factors affect the diversity of the regional fauna.

Small mammal faunas in the study region were actively studied beginning in the $18^{\text {th }}$ century (Pallas, 1788; Radde, 1861; Cherkasov, 1867; Kuznetsov, 1929; Skalon, 1935; Fetisov, 1944; Nekipelov, 1960). The amount of faunal data varies with locality. Large areas within the region lack faunal studies primarily because they are remote areas without a transportation network.

\section{Materials and methods}

We analysed a part of Transbaikalia, located within the Amur River basin and the undrained area of the
Uldza-Torey Plain. This territory is bounded in the west and north by the line of the Amur watershed, in the east by the $123^{\circ} \mathrm{E}$ meridian, and in the south by the national boundaries between Russia, Mongolia and China (Fig. 1). Southern artificial boundary was chosen because of sharp difference in data abundance between states.

\section{Mammal data and species distribution mod-} elling

We used 47 species distribution models of representatives of the orders Eulipotyphla, Chiroptera, Rodentia and Lagomorpha from our previous study (Lissovsky \& Obolenskaya, 2015) as our initial data for zoning: Daurian hedgehog Mesechinus dauuricus (Sundevall, 1841); tundra shrew Sorex tundrensis Merriam, 1900; Siberian large-toothed shrew Sorex daphaenodon Thomas, 1907; flat-skulled shrew $S$. roboratus Hollister, 1913; Laxmann's shrew S. caecutiens Laxmann, 1788; taiga shrew S. isodon Turov, 1924; Eurasian least shrew S. minutissimus Zimmermann, 1780; eastern water bat Myotis petax Hollister, 1912; Brandt's bat M. brandti (Eversmann, 1845); steppe whiskered bat $M$. aurascens Kuzyakin, 1935; brown long-eared bat Plecotus auritus (Linnaeus, 1758); northern bat Eptesicus nilssoni (Keyserling et Blasius, 1839); particoloured bat Vespertilio murinus Linnaeus, 1758; Asian particolored bat Vespertilio sinensis (Peters, 1880); 
flying squirrel Pteromys volans (Linnaeus, 1758); Eurasian red squirrel Sciurus vulgaris Linnaeus, 1758; Siberian chipmunk Tamias sibiricus (Laxmann, 1769); long-tailed ground squirrel Spermophilus undulatus (Pallas, 1778); Daurian ground squirrel S. dauricus Brandt, 1843; tarbagan marmot Marmota sibirica (Radde, 1862); Mongolian five-toed jerboa Allactaga sibirica (Forster, 1778); striped hamster Cricetulus barabensis (Pallas, 1773); Campbell's dwarf hamster Phodopus campbelli (Thomas, 1905); Amur brown lemming Lemmus amurensis Vinogradov, 1924; wood lemming Myopus schisticolor (Lilljeborg, 1844); gray red-backed vole Myodes rufocanus (Sundevall, 1846); northern red-backed vole M. rutilus (Pallas, 1779); Maximovicz's vole Alexandromys maximowiczii (Schrenck, 1859); Mongolian vole Microtus mongolicus (Radde, 1861 ); reed vole $A$. fortis (Büchner, 1889); narrowheaded vole Lasiopodomys gregalis (Pallas, 1779); Brandt "s vole L. brandtii (Radde, 1861); North China zokor Myospalax psilurus (Milne-Edwards, 1874); steppe zokor M. aspalax (Pallas, 1776); Armand's zokor M. armandii Milne-Edwards, 1867; Mongolian gerbil Meriones unguiculatus (Milne-Edwards, 1867); brown rat Rattus norvegicus (Berkenhout, 1769); house mouse Mus musculus Linnaeus, 1758; striped field mouse Apodemus agrarius (Pallas, 1771); Korean field mouse A. peninsulae (Thomas, 1906); harvest mouse Micromys minutus (Pallas, 1771); northern pika Ochotona hyperborea (Pallas, 1811); Manchurian pika O. mantchurica Thomas, 1909; Hoffmann's pika O. hoffmanni Formosov et al., 1996; Daurian pika O. dauurica (Pallas, 1776); mountain hare Lepus timidus Linnaeus, 1758; tolai hare L. tolai Pallas, 1778. Below, we briefly describe the methods used to obtain these models because they are closely related to the methods used in this study.

Localities for the 47 species were used to construct the distribution models. We combined these taxa under the conditional name "small mammals". All of the information used for the study was obtained from museum specimen labels. We analysed approximately 3000 specimens from five museums, which had been collected by 81 zoologists from the middle of the $19^{\text {th }}$ century to the present (Lissovsky \& Obolenskaya, 2015).

Since museum data have some limitations as initial data for species distributions modelling (Newbold, 2010), we checked species identification for every specimen and paid special attention to identification of localities' coordinates.

We determined the coordinates for 453 specimen localities (Appendix 1) using publications (field routes descriptions, publications mentioning collecting points) and topographic maps (beginning in the $19^{\text {th }}$ century) with scales of 1:200 000 and 1:100 000. Some specimens (including ours) had already been assigned GPS coordinates.

The maximum entropy method (Phillips et al., 2006; Phillips \& Dudik, 2008; Elith et al., 2011) was selected for the species distribution modelling. We used the environmental variables described below for distribu- tion extrapolation. A special raster layer, characterising the "availability" of the territory for zoologists, was used to avoid the calculation shift caused by the irregularity of visits to different parts of the region by the collectors.

Each model was built 10 times based on random sampling $(60 \%)$ from all localities available for every species. We calculated the final model as the average of the results of the 10 iterations described above. We performed additional checks on the models during the 2011 field season (Lissovsky \& Obolenskaya, 2015).

Distribution models constructed for 37 of 47 species were considered successful and corresponded to all of the available data on small mammal distributions in South-East Transbaikalia. Six distribution models: Brandt "s vole, Mongolian gerbil, Maximovicz's vole, reed vole, northern pika and Manchurian pika deviated from the observed distribution of the species in nature. The models for Brandt's vole and the Mongolian gerbil included uninhabited enclaves. The distributions of the remaining four species were interdependent with closely related species or "competitors". The data of these six models included the removal of the unpopulated enclaves and transferring one part of Maximovicz's vole range model of the upper Onon River to the Reed vole model. These alterations successfully transformed these models. Another four distribution models of species known in the region that were based on only 2-3 reported occurrences: northern bat, Amur brown lemming, Hoffmann's pika, flying squirrel deviated from the reported distribution in nature (Lissovsky \& Obolenskaya, 2015). However, these four models apply to very small areas and do not significantly shift the zoning results.

\section{Environmental data}

The total area of South-Eastern Transbaikalia is $269602 \mathrm{~km}^{2}$. A raster network with a pixel size of $0.02^{\circ}$ was selected for species distribution modelling and faunal typification of the region. This pixel size reflects the scale of the initial environmental data and reduces potential errors arising from incorrect geographical coordinate identification decoding the museum labels. The average area of the raster cells (analysed territorial units - ATU) was $3.2 \mathrm{~km}^{2}$.

The environmental data comprised the following:

1) A remote survey from the scanning system MODIS of the Terra satellite with a resolution of $500 \mathrm{~m}$ (http://glcf.umiacs.umd.edu/data/). We used generalised average monthly data for February, July and October, 2001. Our choice of these months reflects the three principal seasons in South-Eastern Transbaikalia. Seven sets of spectral brightness, corresponding to the seven bands of the scanning system, were obtained for each of the three seasons. We also calculated the normalised difference vegetation index (NDVI) (Carroll et al., 2003) for summer (Appendix 2).

2) WorldClim global climate data with a resolution of $30^{\prime \prime}$ (>1 km) (http://www.worldclim.org) (Hijmans 
et al., 2005). We used 19 "bioclimatic" variables (Appendix 2) that were hypothetically relevant to the distribution of biological objects. These variables are commonly used for species distribution modelling (Hijmans et al., 2005; Nobrega \& Marco, 2011).

3) A GIS layer ("maxentpopul") comprising regional objects that indicate settlements (created based on a map with a scale of 1:1000000). We used this layer together with environmental variables solely for modelling the synanthropic species distribution (Appendix 2).

Initial standardized variables were transformed into mutually orthogonal variables using principal component analysis (climate and satellite data were transformed separately). These principal components, which together described the natural conditions of the region, were considered as the environmental factors. Only factors with non-random spatial distribution were selected for further analysis (Lissovsky \& Obolenskaya, 2015) (Appendix 2).

\section{Clustering methods}

We recoded the relative likelihood values from Maxent to convert the modelled ranges to binary form ("1" — suitable area, "0" — unsuitable area). The lower tenth percentile of the relative likelihood of the species detection in the training set was taken as the threshold. The relative likelihood values lower than the threshold were set to zero, and those higher than the threshold were set to one. Fixed threshold in our study with standard methods of animals capture simulates a kind of detectability.

All information on the distribution model was summarised in a table containing 47 columns (species) and 83551 rows (ATUs). Each table cell contained either a " 1 " or " 0 ". We condensed the table for further analysis by selecting a set of rows with a unique set of species (elementary faunas - EFs). There were 29331 EFs. Due to technical limitations of the software as well as the zoogeographic reasonableness, we excluded EFs that occurred on the regional map as only 1, 2 or 3 ATUs. The resulting table contained 3348 rows.

We calculated 1-Jaccard similarity coefficients (Jaccard, 1901) to assess the dissimilarity of the EFs. We conducted typification of fauna using hierarchical cluster analysis with the Ward and unweighted average (UPGMA) methods. Cluster membership of excluded EFs that occurred on the map as only 1,2 or 3 ATUs was determined using a canonical discriminant analysis.

\footnotetext{
Distribution of fauna in the spaces of environmental factors

Analysis of the spatial distribution of small mammal species across the region (the number of species in each ATU and the area occupied by each FE) was conducted using the GIS package Mapinfo 11.0.

Recoding of the modelling results (converting probabilities to binary) was performed using the GIS package ScanEx Image processor 3.0. We used the GIS
}

package DIVA-GIS 7.3.0 for data visualisation. Mapping was performed using the GIS package Mapinfo 11.0. All maps were designed using Kavrayskiy's equidistant conic projection.

We calculated Jaccard coefficients (using original script), standardized variables, cluster analysis, discriminant analysis, correlations between the number of species and the latitude, longitude, altitude and regional environmental factors; the relationship between the spatial heterogeneity of the regional fauna (faunal clusters and subclusters) and distribution of environmental factors using Statistica 8.0 (StatSoft, 2007).

\section{Results}

\section{Spatial distribution of species}

Each EF contained from 1 to 29 species with an average of $11.4 \pm 4.4$ species. Species richness estimated from stacked SDM seems to be overestimated (Trotta-Moreu \& Lobo, 2010; Guillera-Arroita et al., 2015), however we can use our result as relative estimate. The smallest number of species occurred in the taiga (Fig. 2 ). Watersheds and peaks of mountain ranges in the taiga showed the poorest species distribution. A greater number of species inhabits the intermountain basins in the forest zone. Flood-lands and forest-steppe showed a greater diversity of fauna. Steppes are inhabited by a greater number of species compared to taiga and foreststeppe territories. The maximum number of species was found in the steppe along the Argun' River.

The correlation between the species number and latitude, longitude or altitude was poor $(\mathrm{r}=-0.13,-0.53$ and -0.25 , respectively). Humid summer conditions showed the highest correlation between species numbers and environmental factors $(r=0.68)$. The absolute values of the correlation coefficients for the other environmental factors were less than 0.45 .

The area occupied by each EF varied between 1 to 791 ATUs. The average area inhabited by each EF in the region was $2.8 \pm 12.3$ ATUs. A considerable proportion $(70 \%)$ of the EFs occurred on the map only once, with $12 \%$ occurring in two ATUs and 5\% occurring in three ATUs. In general, those faunas inhabiting a larger area were more rare.

EFs occurred on the map once, twice or thrice occupied the steppe and forest-steppe areas in the region within a wide band (Fig. 3). These EFs also occurred in the taiga. EFs with maximally occupied areas were located in the taiga or the mountain taiga in the northern, north-eastern and eastern parts of the region.

\section{Faunal cluster results}

The commonly used UPGMA method of clustering (Hagmeier \& Stults, 1964; Neronov, 1976; Neronov \& Arsenyeva, 1980) yielded distances between clusters that were too small, and therefore, it was difficult to elucidate the cluster structure. We applied the Ward method, which is also commonly used (Simpson, 1964; 


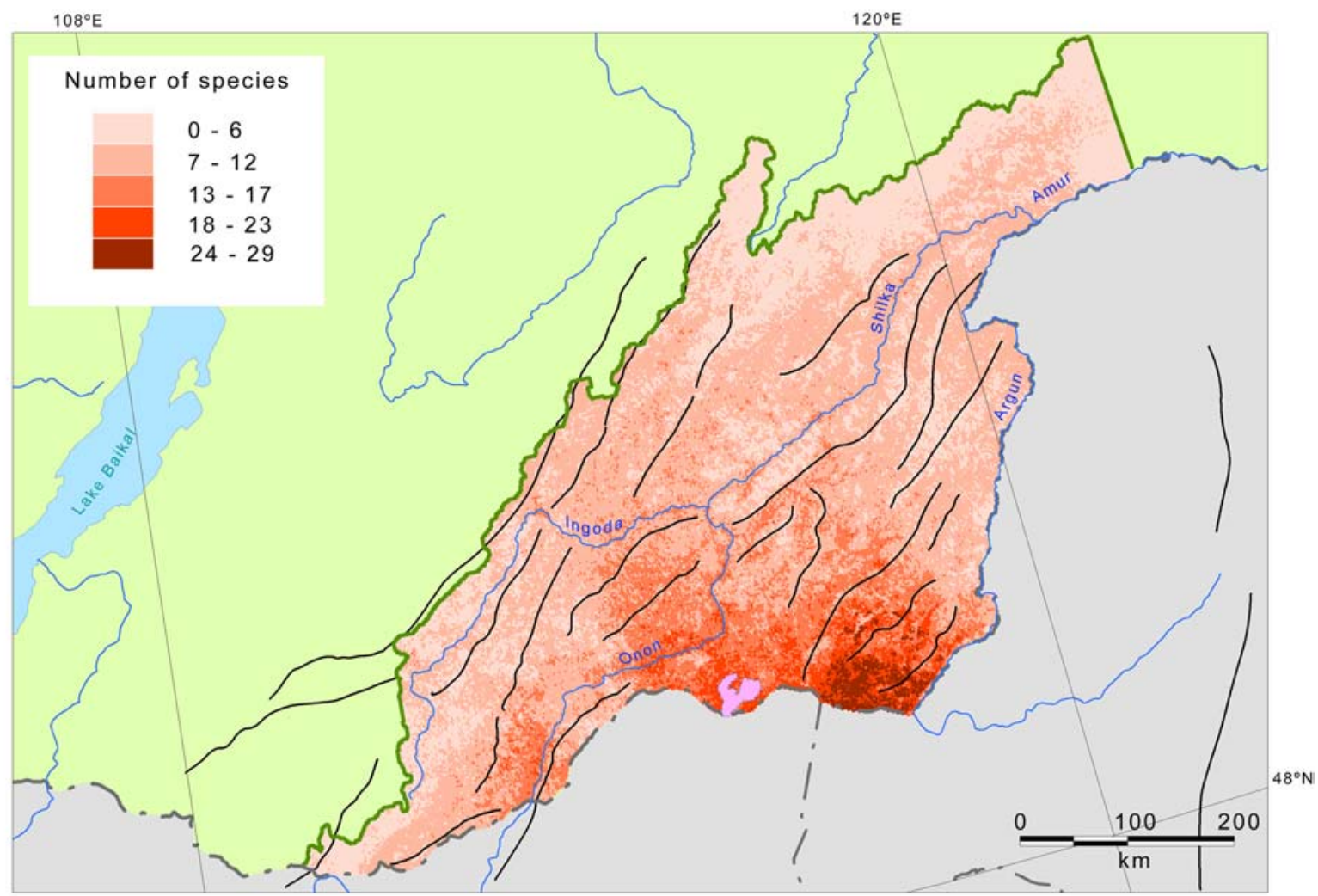

Figure 2. Potential species richness based on distribution model predictions in South-Eastern Transbaikalia. The map is presented using the Kavraiskiy conical intermediate projection.



Figure 3. Faunistic homogeneity of the territory of South-Eastern Transbaikalia. ATU is analysed territorial unit. The map is presented using the Kavraiskiy conical intermediate projection. 


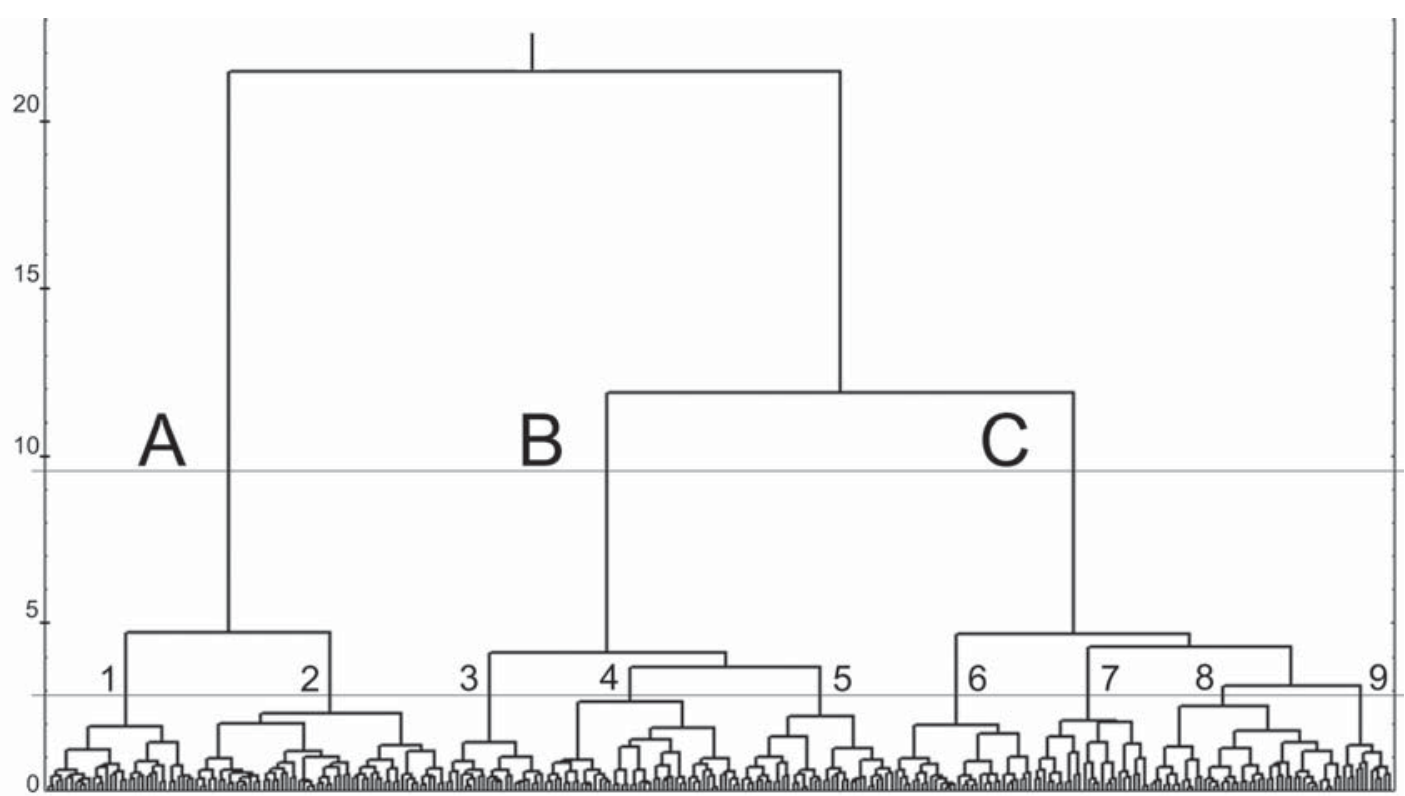

Figure 4. Dendrogram of similarity of elementary faunas of South-Eastern Transbaikalia using 1-Jaccard coefficients. Ward method; hierarchical cluster analysis. A, B, C: strong boundary; 1-9: weak boundary.



Figure 5. Spatial localisation of faunal clusters (A, B, C) on the territory of South-Eastern Transbaikalia. The map is presented using the Kavraiskiy conical intermediate projection.

Kaiser et al., 1972; Wilson, 1974; Skulkin \& Puzachenko, 1986; Xiang et al., 2004; Heikinheimo et al., 2007).

Cluster analysis of EFs revealed three large clusters with nine subclusters (Fig. 4) showing a clear spatial localisation (Fig. 5).
EFs from cluster A included eight species occurring only within this cluster, we propose to call them exclusive species (by analogy with Braun-Blanquet classification); seven species occurring in more than $70 \%$ of ATUs in this cluster, we propose to call them selective 
Table 1. Description of the faunal clusters A, B and C (qualitative and quantitative composition).

\begin{tabular}{|c|c|c|c|c|}
\hline $\begin{array}{l}\text { Faunal } \\
\text { clusters }\end{array}$ & Exclusive species & Selective species & Preferential species & $\begin{array}{l}\text { Spatial localisation of } \\
\text { the analysed territorial } \\
\text { units }\end{array}$ \\
\hline$A$ & $\begin{array}{l}\text { Striped field mouse, tarbagan } \\
\text { marmot, Mongolian gerbil, } \\
\text { Daurian ground squirrel, } \\
\text { Campbell's dwarf hamster, } \\
\text { Hoffmann's pika, steppe } \\
\text { whiskered bat, Armand's } \\
\text { zokor }\end{array}$ & $\begin{array}{l}\text { Particoloured bat, } \\
\text { tundra shrew, striped } \\
\text { hamster, Daurian } \\
\text { pika, Daurian } \\
\text { hedgehog, harvest } \\
\text { mouse, Mongolian } \\
\text { five-toed jerboa } \\
\end{array}$ & $\begin{array}{l}\text { Brown rat, brown } \\
\text { long-eared bat, } \\
\text { narrow-headed vole, } \\
\text { tarbagan marmot, } \\
\text { Brandt's vole, } \\
\text { Siberian large- } \\
\text { toothed shrew }\end{array}$ & $\begin{array}{l}\text { South steppes: along the } \\
\text { Argun River, on the } \\
\text { Uldza-Torey Plain, in } \\
\text { the upper stream of the } \\
\text { Onon River }\end{array}$ \\
\hline$B$ & - & $\begin{array}{l}\text { Siberian chipmunk, } \\
\text { Korean field mouse, } \\
\text { tundra shrew }\end{array}$ & $\begin{array}{l}\text { Maximovicz's vole, } \\
\text { striped hamster, } \\
\text { harvest mouse, } \\
\text { brown rat, long-tailed } \\
\text { ground squirrel, gray } \\
\text { red-backed vole }\end{array}$ & $\begin{array}{l}\text { Forest-steppe territories } \\
\text { in the South of the } \\
\text { Argun-Shilka } \\
\text { interfluve; the valleys } \\
\text { within basins of the } \\
\text { Onon River and the } \\
\text { Ingoda River; the upper } \\
\text { stream of the Shilka } \\
\text { River }\end{array}$ \\
\hline$C$ & Brandt's bat & Siberian chipmunk & $\begin{array}{l}\text { Laxmann's shrew, } \\
\text { gray red-backed vole, } \\
\text { taiga shrew, Korean } \\
\text { field mouse }\end{array}$ & $\begin{array}{l}\text { Plain and mountain } \\
\text { taiga in the basins of the } \\
\text { Ingoda River, the Shilka } \\
\text { River, the Argun-Shilka } \\
\text { interfluve }\end{array}$ \\
\hline
\end{tabular}

species; six species occurring in more than half of the ATUs in this cluster, we propose to call them preferential species (Allaby, 2004). Cluster B had no exclusive species but included three selective species and six preferential species. Cluster $\mathrm{C}$ had one exclusive species, one selective species and four preferential species (Tab. 1).

Clusters A and B together had several species that do not live outside of this aggregated area, including the Mongolian five-toed jerboa, the Daurian hedgehog, Brandt "s vole, tolai hare and the Daurian pika. By combining clusters $\mathrm{B}$ and $\mathrm{C}$, the following exclusive species were obtained: the flying squirrel, the Northern pika and the taiga shrew.

No exclusive species occurred in any of the nine subclusters. The lowest number of selective species occurred within subclusters B5 and C9. Selective species were absent from subcluster $\mathrm{C} 7$; this subcluster showed the lowest number of species.

EFs covering minor areas (1-3 ATUs) were distributed between clusters $\mathrm{A}, \mathrm{B}$ and $\mathrm{C}$ in nearly equal proportions: 7569, 9315 and 9099 ATUs in clusters A, B and $\mathrm{C}$, respectively.

\footnotetext{
Distribution of fauna in the space of environmental factors

Territories covered with EFs from clusters A, B and $\mathrm{C}$ were successfully localised in a multidimensional hyperspace of environmental factors (Fig. 6) (Wilks = $0.17, \mathrm{p}<0.01)$. Territories of clusters $\mathrm{A}$ and $\mathrm{C}$ could be
}

distinguished by discriminant analysis with an accuracy of 0.98 . Summer humidity conditions (correlation with the first canonical axis $r=0.77)$, NDVI values $(r=$ 0.77 ) and the ecosystems humidity characteristic $(r=$ 0.62) had the greatest impact on this discrimination. The general resolution of the system with three clusters was 0.87 . The accuracy of the determination of the territory of cluster B was 0.71 . The territory of cluster B widely overlapped with the territories of two other clusters in the hyperspace of environmental factors (Fig. 6). Territories of subclusters could be explained by environmental factors with a lower accuracy (Tab. 2).

\section{Discussion}

The weak differentiation of clusters using the UPGMA method indicates an absence of sharp spatial borders between faunas. The EFs of cluster A evidently reside in the steppe zone, whereas the EFs of cluster C occur in the taiga; from an ecological perspective, the exclusive and selective species of clusters A and C are steppe (Kucheruk, 1959) and taiga (Kulik, 1972) species, respectively.

\section{Faunal clustering}

Three large clusters, each with its own internal structure, can be distinguished at the first hierarchical level. We could not determine the next lowest hierarchical level of the EF spatial distribution using the dendrogram alone. Thus, we describe the most discrete 


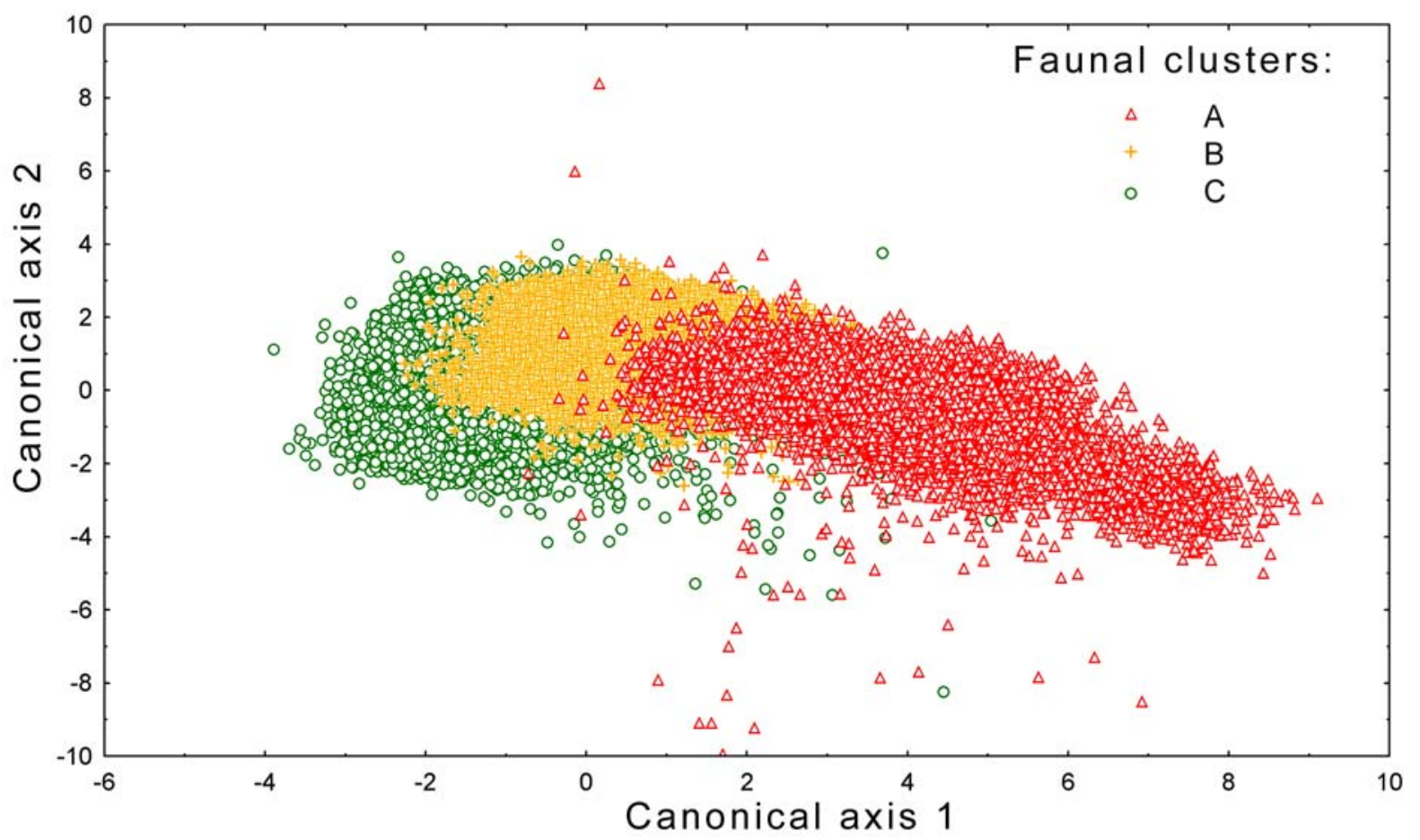

Figure 6. Distribution of members of faunal clusters in the canonical space of environmental factors.

Table 2. Separation of the faunal subclusters by canonical discriminant analysis based on environmental factors

\begin{tabular}{|l|c|c|l|}
\hline $\begin{array}{c}\text { Pairs of faunal } \\
\text { subclusters }\end{array}$ & $\begin{array}{c}\text { \% of correct } \\
\text { determination }\end{array}$ & $\begin{array}{c}\text { Maximal correlation } \\
\text { with environmental } \\
\text { factors }\end{array}$ & \multicolumn{1}{|c|}{ Discriminating environmental factors } \\
\hline A1 and A2 & 94 & 0.6 & Daily temperature difference \\
\hline B3 and B4 & 89 & 0.53 & Ecosystems humidity characteristic \\
\hline B3 and B5 & 86.5 & 0.52 & Biological productivity of vegetation \\
\hline B4 and B5 & 93.4 & 0.7 & Characteristics of vegetation cover \\
\hline C9 and C6 & 93.4 & 0.6 & Daily temperature difference \\
\hline C9 and C7 & 93.4 & 0.44 & $\begin{array}{l}\text { Differences in the physical objects in the visible part of } \\
\text { the spectrum (rocks, water bodies, anthropogenic } \\
\text { objects, etc.) }\end{array}$ \\
\hline C9 and C8 & 77 & 0.57 & Summer humidity conditions \\
\hline C6 and C7 & 77 & 0.45 & Biological productivity of vegetation \\
\hline C6 and C8 & 77 & 0.55 & Summer humidity conditions \\
\hline C7 and C8 & & 0.44 & Characteristics of vegetation cover \\
\hline
\end{tabular}

variant with nine units to discuss ways to unite these subclusters based on faunal similarity.

There are fewer fauna in subcluster A2 than in A1, and these units differ in their composition. The two subclusters include both shared and selective species.

The faunas of subclusters B4 and B5 are highly similar (they differ in three species per subcluster). In general, the shared species (the gray red-backed vole, Maximovicz's vole, the striped hamster, the long-tailed ground squirrel, the Siberian chipmunk, the Korean field mouse, Laxmann's shrew, and the tundra shrew) are characteristic of the interpenetration zone of the steppe and taiga faunas in South-Eastern Transbaikalia. Exclusive species in subclusters allow western and east- 




Figure 7. Zoogeographical zoning $\left(0.02^{\circ}\right.$ grid cells $)$ using species distribution modelling with the example of small mammals of South-Eastern Transbaikalia. The map is presented using the Kavraiskiy conical intermediate projection.

ern variants of the interpenetration zone to be differentiated.

The faunas of subcluster B3 differ considerably from the subclusters B4 and B5. The faunas of subcluster B3 lack three of the eight species listed above as characteristic of the interpenetration zone. Additionally, six species are shared with the steppe faunas A1 and A2 (B4 and B5 have only three such steppe species). Thus, subcluster B3 differs more from subclusters B4 and B5 than subclusters B4 and B5 differ between themselves.

The differences between the four subclusters in $\mathrm{C}$ are minor. Subclusters $\mathrm{C} 6$ and $\mathrm{C} 8$ differ with respect to two species: subclusters $\mathrm{C} 7$ and $\mathrm{C} 8$ differ with respect to one species, and subcluster $\mathrm{C} 9$ differs from $\mathrm{C} 6$ and C8 with respect to one species. Thus, faunas in C6, C7 and $\mathrm{C} 9$ are only specific variants of the $\mathrm{C} 8$ fauna. The absence of exclusive species within any of the nine subclusters reflects their low faunistic rank.

Finally, we can turn from the discussion of clusters to units of spatial typification of the regional fauna. We can consider clusters $\mathrm{A}, \mathrm{B}$ and $\mathrm{C}$ as spatial groups of fauna. According to our results (Tab. 1; Figs 4-6) on the qualitative and quantitative composition of the clusters (exclusive, selective, preferential species), as well as their spatial locations, we can, for convenience, name the faunal groups $\mathrm{A}, \mathrm{B}$ and $\mathrm{C}$ as the steppe, the taiga-steppe and the taiga faunal groups, respectively.
We believe that it is rational to also assign two ranks of lower hierarchy. Larger differences between subclusters, such as between subclusters A1 and A2 or B3 and B4 and B5, may be considered as faunal subgroups. Minor differences of 1-3 species can be assigned to a lower hierarchical level and considered as faunal variants. Such a difference occurs in subclusters B4 and B5; the group of subclusters consists of C6, C7, C8 and C9 (Fig. 7).

Considering species lists in the absence of a spatial context reveals that the taiga-steppe faunal group has a mixed composition, indicated by an absence of exclusive species, a mixed set of selective species, and a notable increase in exclusive species in the pairs A + B and $\mathrm{C}+\mathrm{B}$. In fact, the taiga-steppe faunal group has no unique elements but comprises elements of the steppe and taiga faunal groups.

Thus, there are two independent faunas in SouthEastern Transbaikalia, "steppe" and "taiga", whereas considerable territory is occupied by an interpenetration zone.

The steppe faunal group has the largest number of species, clear subdivisions, and the largest number of exclusive species. Thus, the steppe group is richer, spatially heterogeneous and more isolated; i.e., a larger number of steppe species do not penetrate into the area inhabited by the taiga faunal group than vice versa. 
The taiga faunal group, on the contrary, is poorer in species composition, more spatially homogeneous, and less isolated. Such characteristics occur for the taiga faunal species including the northern red-backed vole, the gray red-backed vole, the Siberian chipmunk, and Laxmann's shrew (Kulik, 1972) that are widely distributed in South-Eastern Transbaikalia among species of the "steppe" fauna. This phenomenon can be observed in the steppe slope region, on steppe river floodplains or in pine forests with steppe vegetation in the grass cover. Only the Flying squirrel, the northern pika, the taiga shrew and Brandt's bat can be recognised among species occurring only in the area where taiga fauna occur.

\section{Fauna and environmental factors}

Although species richness in the region has no strong correlation with environmental factors, some of our units of spatial typification of fauna of South-Eastern Transbaikalia could be successfully explained by the multidimensional distribution of environmental factors. However, only two units with the highest rank could be specified using environmental data with a probability greater than $95 \%$. The interpenetration zone was poorly correlated with the distribution of environmental factors. The poor correlation could be explained in part by technical problems. Obviously, if the territory mosaicism is higher than the selected size of the ATU, the environmental data in raster cells will reflect an "average" of the steppe and taiga parameters.

Lower rank spatial typification units were even more poorly correlated with the distribution of environmental factors (Tab. 2). The best prediction of faunal units by environmental data was possible only using a pairwise comparison. The total resolution of the discriminant analysis of several subclusters together (even from one bigger cluster) was very low.

We return here to the methodological problem of extrapolating faunal data. Using an extrapolation of each species distribution, we obtained 29331 EFs (and 3348 EFs occurring more than three times). If faunal zoning without species distribution modelling is to be performed with the same level of accuracy, it will be necessary to identify a large number of species combinations in nature or using an analytical approach. Even if some level of accuracy is possible, faunal extrapolation based on environmental data will yield a weak resolution.

Thus, the species distribution modelling approach allows us to manage the problem of discrete faunal data extrapolation to a larger territory. Modelling methods can be further improved by obtaining a complete matching of models and a real distribution of animals. However, even in the modern environment, the use of such models is considerably better compared with visual filling of spatial units with lists of taxa. Raster cells of the same size in modelling and further cluster formation allow the avoidance of additional calculation inaccuracy. Concluding, analysis of stacked distribution models could be an important tool for investigation of regional zoogeographical heterogeneity.

ACKNOWLEDGEMENTS. We are grateful to Yu.G. Puzachenko, A.M. Barbosa, Yu.S. Ravkin and L.A. Khlyap for their discussion and constructive comments. We thank S.M. Malhazova, E.G. Myalo, and T.V. Kotova for providing useful advice. We thank M.N. Dementiev and R.B. Sandlerskiy for their help in solving certain technical problems. We also thank all members of our expedition in South-Eastern Transbaikalia, especially A.E. Pilnikov and S.V. Kruskop. Furthermore, we thank the people who provided logistical support for our field work.

This work was financially supported in part by the Russian Foundation for Basic Research grants 07-0410059, 09-04-10110, 11-04-10066, 14-05-31476.

\section{References}

Afanas'ev A.V. 1960. [Zoogeography of Kazakhstan (on the basis of mammal distribution)]. Alma Ata: Izdatel'stvo Akademii Nauk Kazakhskoy SSR. 535 p. [in Russian].

Allaby M. 2010. A Dictionary of Ecology. 4 edition. Oxford, New York: Oxford University Press. 432 p.

Arefyeva V.A., Vendrov S.A., Dreier N.N. \& Rossolimo L.L. 1965. [Waters] // Preobrazhenskiy V.S. (ed.). [Cisbaikalia and Transbaikalia]. Moscow: Nauka. P.139183 [in Russian].

Bannikov A.G. 1954a. [Mammals of the Mongolian People Republic]. Moscow-Leningrad: Izdatel'stvo Akademii Nauk SSSR. 669 p. [in Russian].

Bannikov A.G. 1954b. [Zoogeographical regions of Mongolia and history of formation of mammalian fauna of the country] // Baranskiy N.N. (ed.). [Questions of geography]. Moscow: Geographgiz. P.28-37 [in Russian].

Barbosa A.M., Estrada A., Márquez A.L., Purvis A. \& Orme D.C.L. 2012. Atlas versus range maps: robustness of chorological relationships to distribution data types in European mammals // Journal of Biogeography. Vol.39. No.8. P.1391-1400.

Carroll M.L., Di Miceli C.M., Sohlberg R.A. \& Townshend J.R.G. 2003. 250*m MODIS Normalized Difference Vegetation Index. Maryland: University of Maryland.

Cherkasov A.A. 1867. [Memorials of East Siberian Hunter]. St. Petersburg: Izdatel'stvo S.V. Zvonareva. 707 p. [in Russian].

Chernyavskiy F.B. 1978. [The problem of zoning in land zoogeography and subdivision of Northeast Siberia on the basis of mammological data] // Kontrimavichus V.L. (ed.). [Fauna and zoogeography of mammals of the NorthEast Siberia]. Vladivostok: Izdatel'stvo Dalnevostochnogo Nauchnogo Tsentra Akademii Nauk SSSR. P.3-25 [in Russian].

Darlington P.J., Jr. 1957. Zoogeography: the geographical distribution of animals. London: Chapman and Hall. $675 \mathrm{p}$.

Elith J., Phillips S.J., Hastie T., Dudik M., Chee Y.E. \& Yates C.J. 2011. A statistical explanation of MaxEnt for ecologists // Diversity and Distributions. Vol.17. No.1. P.43-57. 
Escalante T., Rodríguez-Tapia G., Szumik C., Morrone J.J. \& Rivas M. 2010. Delimitation of the Nearctic region according to mammalian distributional patterns // Journal of Mammalogy. Vol.91. No.6. P.1381-1388.

Ferrier S. \& Guisan A. 2006. Spatial modelling of biodiversity at the community level // Journal of Applied Ecology. Vol.43. No.3. P.393-404.

Fetisov A.S. 1944. [Rodents of South Transbaikalia] // Vestnik Irkutskogo Gosudarstvennogo Protivochumnogo Instituta Sibiri i Dalnego Vostoka. Vol.5. P.15-40 [in Russian].

Galanin A.V., Belikovich A.V. \& Royenko E.N. 2009. [Synopsis of dendroflora of Dahuria] // Bulleten' Botanicheskogo Sada Instituta Dalnevostochnogo Otdeleniya Rossiyskoy Akademii Nauk. No.3. P.4-32 [in Russian].

Guillera-Arroita G., Lahoz-Monfort J.J., Elith J., Gordon A., Kujala H., Lentini P.E., McCarthy M.A., Tingley R. \& Wintle B.A. 2015. Is my species distribution model fit for purpose? Matching data and models to applications: matching distribution models to applications // Global Ecology and Biogeography. Vol.24. No.3. P.276-292.

Hagmeier E.M. 1966. A numerical analysis of the distributional patterns of North American mammals // Systematic Zoology. Vol.15. No.4. P.279-300.

Hagmeier E.M. \& Stults C.D. 1964. A numerical analysis of the distributional patterns of North American mammals / / Systematic Zoology. Vol.13. No.3. P.125-155.

Heikinheimo H., Fortelius M., Eronen J. \& Mannila H. 2007. Biogeography of European land mammals shows environmentally distinct and spatially coherent clusters // Journal of Biogeography. Vol.34. No.6. P.1053-1064.

Heptner V.G. 1936. [General zoogeography]. Moscow-Leningrad: Biomedgiz. 548 p. [in Russian].

Hijmans R.J., Cameron S.E., Parra J.L., Jones P.G. \& Jarvis A. 2005. Very high resolution interpolated climate surfaces for global land areas // International Journal of Climatology. Vol.25. No.15. P.1965-1978.

Isachenko A.G. 1985. [Landscapes of USSR]. Leningrad: Izdatel'stvo LGU. 320 p. [in Russian].

Jaccard P. 1901. Distribution de la flore alpine dans le Bassin des Dranses et dans quelques regions voisines // Bulletin de la Société vaudoise des sciences naturelles. Vol.37. P.241-272.

Kaiser G.W., Lefkovitch L.P. \& Howden H.F. 1972. Faunal provinces in Canada as exemplified by mammals and birds: a mathematical consideration // Canadian Journal of Zoology. Vol.50. No.8. P.1087-1104.

Kimoto S. 1966. A methodological consideration of comparison of insect faunas based on the quantitative method // Esakia. Vol.5. P.1-20.

Kucheruk V.V. 1959. [Steppe faunistic complex of mammals and its position in Palaearctic fauna] // Formozov A.N. (ed.). [Geography of Terrestrial Animal Populations and Methods of Their Study]. Moscow: Izdatel'stvo Akademii Nauk SSSR. P.45-87 [in Russian].

Kulik I.L. 1972. [Taiga faunistic complex of mammals of Eurasia] // Bulleten' Moskovskogo Obshchestva Ispytatelei Prirody. Seriya Biologicheskaya. Vol.77. No.4. P.11-24 [in Russian].

Kurentsov A.I. 1947. [About zoogeographical districts of Primorye Territory] // Komarovskiye chteniya. Vladi- vostok: Izdatel'stvo Dalnevostochnogo Nauchnogo Tsentra Akademii Nauk SSSR. P.5-35 [in Russian].

Kuznetsov B.A. 1929. [Rodents of Eastern Transbaikalia] // Izvestiya Assotsiatsii Nauchno-Issledovatelskih Institutov pri Fiziko-Mathematicheskom Fakultete I MGU. Vol.2. No.1. P.59-106 [in Russian].

Lissovsky A.A. \& Obolenskaya E.V. 2015. A study of the distribution ranges of small mammals in Southeastern Transbaikalia using ecological niche-based modeling methods // Biology Bulletin Reviews. Vol.5. No.3. P.233248.

Lyamkin V.F. 2002. [Ecology and zoogeography of mammals of intermountain depressions of Baikal rift zone]. Irkutsk: Izdatel'stvo Instituta Geographii SO RAN. 116 p. [in Russian].

Márquez A.L., Real R. \& Vargas J.M. 2001. Methods for comparison of biotic regionalizations: the case of pteridophytes in the Iberian Peninsula // Ecography. Vol.24. No.6. P.659-670.

Márquez A.L., Real R., Vargas J.M. \& Salvo A. E. 1997. On identifying common distribution patterns and their causal factors: a probabilistic method applied to pteridophytes in the Iberian Peninsula // Journal of Biogeography. Vol.24. No.5. P.613-631.

Matyushkin E.N. 1972. [Heterogeneity of theriofauna of Ussuri region: its general features, historical roots and contemporary manifestations in communities of the middle Sikhote-Alin] // Rossolimo L.L. \& Dolgov V.A. (eds.). Trudy Zoologicheskogo Muzeya MGU. P.86-144 [in Russian].

Matyushkin E.N., Smirnov E.N. \& Sizova G.I. 1972. [Territorial communities of rodents of middle Sikhote-Alin] // Kucheruk V.V. (ed.). [Fauna and ecology of rodents]. P.116-148 [in Russian].

Mikheev V.S. \& Ryashin V.A. 1967. [Landscapes. Map 1:3500000] // Sochava V.B. (ed.). [Atlas of Transbaikalia (Buryatia and Chita Region)]. Moscow-Irkutsk: Izdatel'stvo GUGK. P.70-71 [in Russian].

Nekipelov N.V. 1960. [Distribution of mammals in SouthEast Transbaikalia and quantity of some species] // Granin A.N. et al. (eds.). [Biological collection]. Irkutsk: Izdatel'stvo Vostochno-Sibirskogo Otdeleniya Geographicheskogo Obshchestva SSSR, Protivochumniy Institut Sibiri i Dalnego Vostoka. P.3-48 [in Russian].

Neronov V.M. 1976. [Zoogeographical analysis of rodent fauna of Iran] // Bulleten' Moskovskogo Obshchestva Ispytatelei Prirody. Seriya Biologicheskaya. Vol.81. No.2. P.32-47 [in Russian].

Neronov V.M. \& Arsenyeva L.P. 1980. [Zoogeographical analysis of rodent fauna of Afghanistan] // Voronov A.G. \& Drozdov N.N. (eds.). [Modern problems of zoogeography]. Moscow: Nauka. P.254-272 [in Russian].

Newbold T. 2010. Applications and limitations of museum data for conservation and ecology, with particular attention to species distribution models // Progress in Physical Geography. Vol.34. No.1. P.3-22.

Newbold T., Reader T., El-Gabbas A., Berg W., Shohdi W.M., Zalat S., El Din S.B. \& Gilbert F. 2010. Testing the accuracy of species distribution models using species records from a new field survey // Oikos. Vol.119. No.8. P.1326-1334. 
Nobrega C.C. \& Marco P.-D.J. 2011. Unprotecting the rare species: a niche-based gap analysis for odonates in a core Cerrado area // Diversity and Distributions. Vol.17. No.3. P.491-505.

Obolenskaya E.V. 2010. [Zoogeographical features of the South-Eastern part of Transbaikal region] // Vestnik MGU. Ser.5. Geographiya. Vol.5. No.5. P.60-66 [in Russian, with English summary]

Olivero J., Márquez A.L. \& Real R. 2013. Integrating fuzzy logic and statistics to improve the reliable delimitation of biogeographic regions and transition zones // Systematic Biology. Vol.62. No.1. P.1-21.

Olyunin V.N. 1975. [Mountains of southern Siberia Plains and mountains of Siberia] // Korzhuev S.S. (ed.). [Geomorphology of the USSR]. Moscow: Nauka. P.245-328 [in Russian].

Pallas P.S. 1788. Travel to different provinces of the Russian Empire. Part 3. St. Petersburg: Press of the Imperial Academy of Sciences. 624 p.

Peshkova G.A. 1985. [Vegetation of Siberia (Cisbaikalia and Transbaikalia)]. Novosibirsk: Nauka. 145 p. [in Russian].

Phillips S.J., Anderson R.P. \& Schapire R.. 2006. Maximum entropy modelling of species geographic distributions // Ecological Modelling. Vol.190. No.3-4. P.231-259.

Phillips S.J. \& Dudik M. 2008. Modeling of species distributions with Maxent: new extensions and a comprehensive evaluation // Ecography. Vol.31. No.2. P.161-175.

Puzachenko Y.G., Kuzmin S.L. \& Sandlerskiy R.B. 2011. [Quantitative estimation of area parameters (with representatives of genus Rana as a case study)] // Zhurnal Obshchei Biologii. Vol.72. No.5. P.339-354 [in Russian, with English summary].

Puzanov I.I. 1938. [Zoogeography]. Moscow: Gosizdat. 361 p. [in Russian].

Radde G.I. 1861. [Travel to South-Eastern Siberia (18551859)] // Zapiski Imperatorskogo Russkogo Geographicheskogo Obschestva. Vol.4. P.1-78 [in Russian].

Ravkin Y.S., Bogomolova I.N. \& Nikolaeva O.N. 2013. The theriofaunistic zoning of northern Eurasia // Contemporary Problems of Ecology. Vol.6. No.1. P.85-93.

Schmoldt A., Benthe H.F. \& Haberland G. 1975. Digitoxin metabolism by rat liver microsomes // Biochemical Pharmacology. Vol.24. No.17. P.1639-1641.

Sclater P.L. 1858. On the general geographical distribution of the members of the class Aves. (Continued) // Journal of the Proceedings of the Linnean Society of London. Zoology. Vol.2. No.8. P.137-145.

Semenov-Tyan-Shanskiy A.P. 1936. [Limits and zoogeographical division of the Palaearctic region for terrestrial animals on the basis of geographical distribution of Coleoptera]. Moscow-Leningrad: Izdatel'stvo Akademii Nauk SSSR. 16 p. [in Russian].

Severtsov N.A. 1877. [On the zoological (mostly ornithological) areas of extratropical parts of our continent] // Proceedings of Russian Geographical Society. Vol.13. No.3. P.125-155 [in Russian].

Shpolyanskaya N.A. 1978. [Permafrost of Transbaikalia]. Moscow: Nauka. 131 p. [in Russian].

Shvetsov Y.G., Smirnov M.N. \& Monakhov G.I. 1984. [Mammals of the Baikal Lake basin]. Novosibirsk: Nauka. 258 p. [in Russian].
Simpson G.G. 1960. Notes on the measurement of faunal resemblance // American Journal of Science. Vol.258-A. P.300-311.

Simpson G.G. 1964. Species density of North American recent mammals // Systematic Zoology. Vol.13. No.2. P.57-73.

Skalon V.N. 1935. [New data on fauna of mammals and birds of Siberia and the Far Eastern Territory] // Vestnik Irkutskogo Gosudarstvennogo Protivochumnogo Instituta Sibiri i Dalnevostochnogo Kraya. Vol.2. P.42-64 [in Russian].

Skulkin V.S. \& Puzachenko Y.G. 1986. [Zoogeographical analysis of mammalian fauna of Mongolia using a computer] // Sokolov V.E. (ed.). [Zoogeographic zoning of MPR]. Moscow: VINITI. P.28-51 [in Russian].

Sochava V.B. (Ed.). 1977. [Landscapes of the south of East Siberia. Map 1:1500000]. Moscow: Izdatel'stvo GUGK. [in Russian].

StatSoft I. 2007. STATISTICA (data analysis software system) version 8.0. StatSoft, Inc., www. statsoft.com.

Tahtadzhan A. 1986. Floristic Regions of the World. First English Language Edition ed. Berkley: University of California Press. 522 p.

Trotta-Moreu N. \& Lobo J.M. 2010. Deriving the species richness distribution of Geotrupinae (Coleoptera: Scarabaeoidea) in Mexico from the overlap of individual model predictions // Environmental Entomology. Vol.39. No.1. P.42-49.

Tupikova N.V. 1982. [Experience of zoogeographic zoning of Altai on the basis of fauna and animal population] // Sokolov V.E. (ed.). [Theoretical and applied aspects of biogeography]. Moscow: Nauka. P.81-99 [in Russian].

Tupikova N.V. \& Komarova L.V. 1979. [Principles and methods of zoological mapping]. Moscow: Izdatel'stvo MGU. 192 p. [in Russian].

Udvardy M.D.F. 1975. A classification of the biogeographical provinces of the world // IUCN Occasional Paper. Vol.18. P.1-49.

Varshavskiy A.A., Neronov V.M. \& Chang I.-Z. 1997. [Zoogeographic zoning arid regions of China (data on the distribution of rodents)] // Zoologicheskii Zhurnal. Vol.76. No.4. P.473-486 [in Russian].

Vosskresenskiy S.S. \& Postolenko G.A. 1967. [The orographic scheme. Map 1:5000000] // Sochava V.B. (ed.). Atlas of Transbaikalia (Buryatia and Chita Region). Moscow-Irkutsk: Izdatel'stvo GUGK. P.12 [in Russian].

Wallace A.R. 1876. The geographical distribution of animals with a study of the relations of living and extinct fauna as elucidating the past changes of the earth's surface. New York: Harper and Brothers. Vol.1. 503 p.

Wiesmann U.N., DiDonato S. \& Herschkowitz N.N. 1975. Effect of chloroquine on cultured fibroblasts: release of lysosomal hydrolases and inhibition of their uptake // Biochemical and Biophysical Research Communications. Vol.66. No.4. P.1338-1343.

Wilson J.W. 1974. Analytical zoogeography of North American mammals // Evolution. Vol.28. P.124-140.

Xiang Z.F., Liang X.C., Huo S. \& Ma S.L. 2004. Quantitative analysis of land mammal zoogeographical regions in China and adjacent regions // Zoological Studies. Vol.43. No.1. P.142-160.

Yudin B.S., Galkina L.I. \& Potapkina A.F. 1979. [Mammals of Altai-Sayan Mountains]. Novosibirsk: Nauka. 296 p. [in Russian]. 
Appendix 1. Initial data used for species distribution modelling. The map is presented using the Kavraiskiy conical intermediate projection (Figure_Appendix 1).




Appendix 2. Description of the environmental factors calculated based on the remote survey of the MODIS scanning system of the Terra satellite (Cosm), Global climate data WorldClim (Clim) and a GIS layer comprising regional objects indicating settlements (maxentpopul).

\begin{tabular}{|c|c|c|}
\hline $\begin{array}{l}\text { Factors } \\
\text { (\% of general } \\
\text { dispersion })\end{array}$ & Correlation with initial variables & Generalized physiographic interpretation \\
\hline Cosm $2(21.1)$ & $1-4$ bands of October scene & Characteristics of vegetation cover \\
\hline Cosm 3 (13.79) & $1-5$ bands of July scene & $\begin{array}{l}\text { Differences in the physical objects in the } \\
\text { visible part of the spectrum (rock outcrops, } \\
\text { water bodies, anthropogenic objects etc.) }\end{array}$ \\
\hline Cosm $4(9)$ & 6,7 bands of February scene & Winter moisture reserves in the ecosystem \\
\hline $\operatorname{Cosm} 5(7.13)$ & $1-5$ bands of July scene, NDVI & Condition of vegetation cover \\
\hline Cosm $6(3)$ & 5-7 bands of October scene & $\begin{array}{l}\text { Autumn moisture reserves in the soil and } \\
\text { vegetation }\end{array}$ \\
\hline Cosm 7 (2.39) & 3-7 bands of July scene & $\begin{array}{l}\text { Summer distribution of common vegetation } \\
\text { types by the moisture content }\end{array}$ \\
\hline Cosm $8(1.11)$ & 6,7 bands of February scene & Winter moisture reserves in the ecosystem \\
\hline $\operatorname{Cosm} 9(0.95)$ & 2 band of July scene & Summer biomass reserve \\
\hline Cosm $11(0.18)$ & 6,7 bands of February scene & Winter moisture reserves in the ecosystem \\
\hline Cosm $12(0.09)$ & 7 bands of February scene & Winter moisture reserves in the ecosystem \\
\hline Cosm $13(0.08)$ & 7 band of October scene & Autumn moisture reserves in the soil \\
\hline NDVI & $\begin{array}{l}\text { Normalized Difference Vegetation Index (B2- B1/ } \\
\text { B2+ B1) }\end{array}$ & Biological productivity \\
\hline Clim2 (22.5) & $\begin{array}{l}\text { Annual mean temperature; precipitation of the wettest } \\
\text { month; maximal temperature of warmest month; } \\
\text { mean temperature of the wettest quarter; mean } \\
\text { temperature of the warmest quarter }\end{array}$ & Summer humidity conditions \\
\hline $\begin{array}{l}\text { Clim4 } \\
(4.6)\end{array}$ & $\begin{array}{l}\text { Max temperature of the warmest month; mean } \\
\text { temperature of the warmest quarter }\end{array}$ & Summer temperature conditions \\
\hline $\begin{array}{l}\text { Clim5 } \\
(3.1)\end{array}$ & Mean diurnal range temperature & Daily temperature difference \\
\hline $\begin{array}{l}\text { Clim8 } \\
(0.3)\end{array}$ & $\begin{array}{l}\text { Precipitation of the driest month; precipitation of the } \\
\text { driest quarter; precipitation of the coldest quarter }\end{array}$ & Winter humidity conditions \\
\hline $\begin{array}{l}\text { Clim9 } \\
(0.2)\end{array}$ & Mean diurnal range of temperature; isothermality & $\begin{array}{l}\text { Annual distribution of the range of } \\
\text { temperature fluctuations }\end{array}$ \\
\hline $\begin{array}{l}\text { Clim10 } \\
(0.1)\end{array}$ & $\begin{array}{l}\text { Precipitation of the driest month; precipitation of the } \\
\text { driest quarter; precipitation of the coldest quarter }\end{array}$ & Winter humidity conditions \\
\hline Maxentpopul & Location of the human settlements & $\begin{array}{l}\text { For modeling of synanthropic species } \\
\text { distribution }\end{array}$ \\
\hline
\end{tabular}

